\title{
EVALUATION OF PRODUCTIVITY AND COSTS OF MALWA FOREST MACHINE IN SANITARY FELLINGS IN LATVIA
}

\author{
*Agris Zimelis ${ }^{1}$, Santa Kalēja ${ }^{1}$, Sergey Ariko \\ ${ }^{1}$ Latvian State Forest Research Institute 'Silava', Latvia \\ ${ }^{2}$ Belarusian State Technological University, Belarus \\ *Corresponding author's email: agris.zimelis@silava.lv
}

\begin{abstract}
The topicality of the study is determined by the increasing demand for sanitary felling services currently mainly provided by manual work. Harvesting using hand-held motor instruments is a physically hard work whose costs are increasing rapidly, but labor availability is declining. In sanitary cuttings, additional complications are caused by the use of conventional machinery in harvesting, which necessitates the creation of wide $(4 \mathrm{~m})$ technological corridors and significantly increases the proportion of damaged remaining trees in a stand (according to past studies, a set of middle-class forest machines in thinning of spruce stands results in 4-5\% of damaged trees, but in pine stands - in approximately twice less damaged trees than in spruce stands). The compact class forest machines in thinnings result in mechanical damage to not more than $1 \%$ of remaining trees. During field trials in sanitary felling 9329 trees were felled. The average productivity working in one shift is $5.35 \mathrm{~m}^{3} \mathrm{~h}^{-1}$ with average stands $10 \mathrm{~cm}$. The cost of harvester's productive hour is $92 €$ but of a forwarder it is 78 . The compact class forwarder creates significantly smaller impact on the soil by reducing ruts depth and soil compaction, which is especially important in sanitary fellings and extraction of seed trees in regenerated areas.
\end{abstract}

Key words: Malwa, sanitary felling, productivity, costs.

\section{Introduction}

The total area of sanitary fellings in Latvia in 2012-2017 was 74.5 thousand ha (average 14.9 thousand ha per year), excluding sanitary clear felling, resulting in 1.7 million $\mathrm{m}^{3}$ of timber (on average 0.35 million $\mathrm{m}^{3}$ per year). Converting to an area units extracted stock in this period was $23.5 \mathrm{~m}^{3} \mathrm{ha}^{-1}$. About half of the area of sanitary fellings has been extracted in state forests, the rest - in private and municipal forests. Seed tree extraction in 20122017 occurred in 1.2 thousand ha area, resulting in 0.2 million $\mathrm{m}^{3}$ of timber ( 238 ha and 39 thousand $\mathrm{m}^{3}$ per year in average). Selective landscape fellings are recorded in the Forest State Registry data since 2014. On average, 0.3 thousand ha are extracted per year in the landscape harvests, producing 3.3 thousand $\mathrm{m}^{3}$ (10 $\mathrm{m}^{3} \mathrm{ha}^{-1}$ on average) (CSP, 2018; Valsts meža dienests, 2019; Zemkopības ministrija, 2018). The thinning and regenerative felling of short-rotation forest plantations will increase in the coming years when short-rotation woody plants planted in the last decades will reach the age of economic use.

Sanitary fellings should be carried out if the impact of one of the risk factors has been recorded biotic (cervids, bark beetle etc.), abiotic (wind, wet snow etc.) and anthropocentric one. An essential role for the carrying out of these fellings is damage caused by cervids game whose impact is essential (Rūba, Miezīte, \& Luguza, 2014; Šñepsts et al., 2018), and wind resulting in significant natural disturbances (Donis et al., 2020; Snepsts et al., 2020; Krisans et al., 2020).

The aim of the study is to determine productivity and prime cost of harvesting and forwarding with a set of Malwa harvesting machines in selective fellings.

\section{Materials and Methods}

The study has been implemented at Forest Research Station, Jaunkalsnavas municipality. In the study, data were collected from 9 forest compartments. The criteria for selection of stands in the sanitary felling is conformity with the following conditons - in spruce and pine forest stands, where the proportion of the dominant tree species is $>60 \%$ and extractable stock at least $10 \mathrm{~m}^{3} \mathrm{ha}^{-1}$, trees damaged or felled by windthrow or insect-damaged trees, the average DBH of the felled trees up to $10 \mathrm{~cm}$, the length of the strip road $<300 \mathrm{~m}$.

The remaining stand in the study is intended to be monitored in the long term, so permanent circular plots are established using the National forest inventory methodology. Plot centers are marked by wooden poles that stay at least $60 \mathrm{~cm}$ above the ground and, additionally, with red color blowing $1 / 3$ of the pole length. Measurements of the DBH of trees are carried out by holding a caliper gauge ruler relative to the center, measured trees are marked by pushing on them the color point, which is focused on the plot center. The tree height is measured as the distance from the root collar to the top with an uncertainty of $\pm 0.5 \mathrm{~m}$. Where an electronic hypsometer is used for measurements; the measuring instrument is calibrated before performing the work.

Templates developed for data collection contain general information on the measured stand, the worker and the date of execution of the work in sanitary cuttings. The forms are filled before and after sanitary felling. To make it easier for the worker to fill in the data, the boxes to be filled are stained according to the required plot radius. In the collars, the damage has to indicate the injury of the measured 
tree if it is externally visible. Separate notes can be added of insect damages, dead laying trees and fallen trees (after strong wind some trees are fallen). To estimate the number of trees in the understorey that can significantly affect productivity rates, all trees in the plot are counted and an average height noted.

In sanitary cuttings, plots are placed on the longest felling diagonal. The first plot is placed with a center of $30 \mathrm{~m}$ from the edges. The smooth deployment of the plots is planned on a felling design by on the longest diagonal. Plot area is $200 \mathrm{~m}^{2}$ (R $7.98 \mathrm{~m}$ ). In the plot, trees are measured by species by separately dividing pine, spruce, birch, aspen, black alder, grey alder, hard deciduous tree species combined; similarly, other soft deciduous tree species are combined too. Stem diameter is measured at $1.3 \mathrm{~m}$ from the root collar. The average is measured by a tree for which $1.3 \mathrm{~m}$ is larger or equal to $3 \mathrm{~cm}$. For the construction of the height curve, height is determined by the species 1 tallest, 1 for shorter and 2 medium-height trees represented in the plot. If there are only individual trees of certain species in the plot, the height has to be measured for all of them.

Eleven work elements related to direct work and 3 elements related to other work operations have been identified for the logging process working time records. Working elements for time studies are:

1. Information fields:

1.1. Working cycle number;

1.2. Diameter of processed tree, $\mathrm{DBH}, \mathrm{cm}$;

1.3. Various notes, travel, strip-road etc.

2. Working time:

2.1. Reaching for tree with crane;

2.2. Positioning of felling head;

2.3. Cutting of tree;

2.4. Delimbing and bucking;

2.5. Log moving and stacking;
2.6. Undergrowth cutting;

2.7. Time spent on driving into a stand;

2.8. Time spent on leaving a stand;

2.9. Other non-standard operations;

2.10. Time spent on activities not related to harvesting;

2.11. Conversations with forest owner.

The notes indicate the reasons for working breaks and other activities. Work time records do not include machine preparation for work that takes approximately 1 hour per day, but the work time records include the lubrication of moving parts carried out during the shift. The amount of fuel consumed for the cost calculation was carried out using the meter AIS Systems.

Data processing is carried out in RStudio. The Shapiro-Wilk Normality test is used to find out whether the data are consistent with normal distribution. The distribution of the number of felled trees in the average grades is described using quartiles by dividing the dataset into equal parts where $25 \%$ of the data volume represents the smallest values, $50 \%$ median, $75 \%$ represents the highest values. Cost calculation is done using a cost model published by S.Kalēja (Kalēja et al., 2018).

\section{Results and Discussion}

The diameter of felled trees ranges from 3 to $30 \mathrm{~cm}$. The smallest processed tree has an average diameter of $3 \mathrm{~cm}, 25 \%$ of processed trees has $7 \mathrm{~cm}$ diameter, $50 \%$ or median has diameter of up to 10 and $75 \%$ of trees has a diameter up to $12 \mathrm{~cm}$. The proportion of felled trees are divided by the diameter classes (Figure 1). According to the studies carried out so far, the productivity is significantly reduced if extracted trees have a diameter less than $6 \mathrm{~cm}$ (Lazdin̄š et al., 2016; Zimelis, Kalēja, \& Okmanis, 2019).

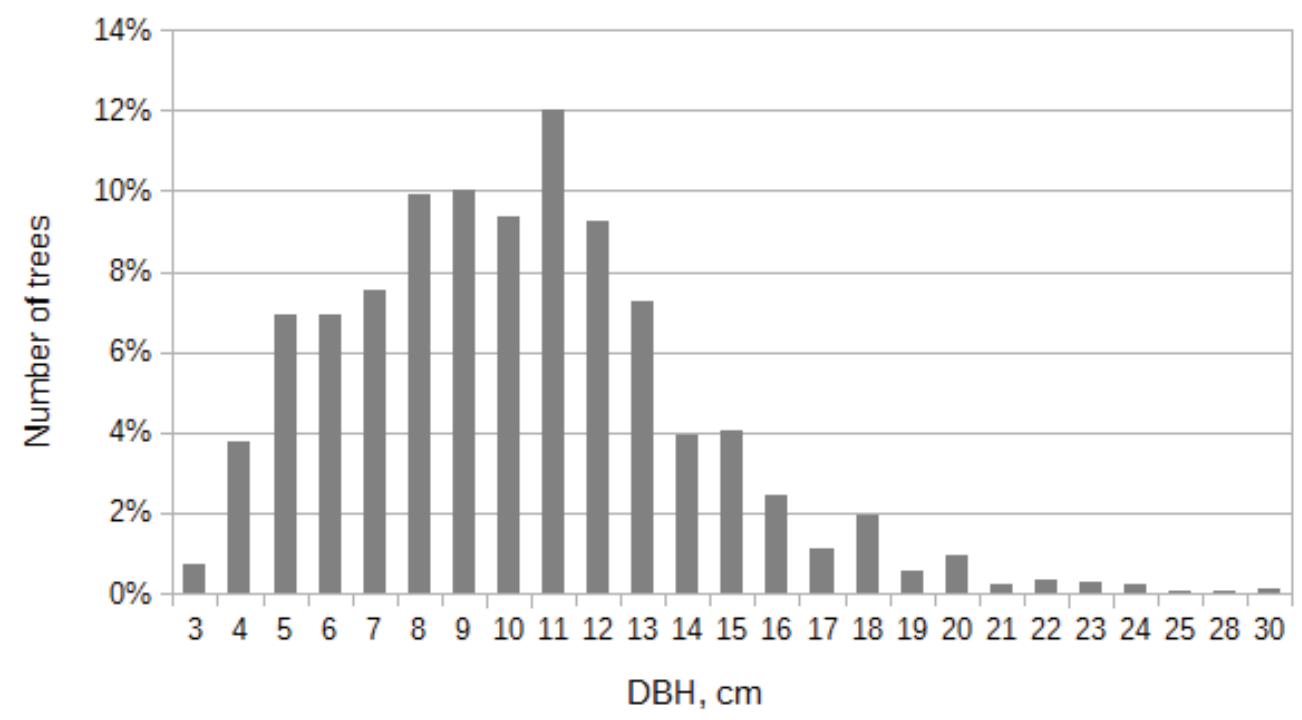

Figure 1. Diameter distribution of trees in sanitary felling. 


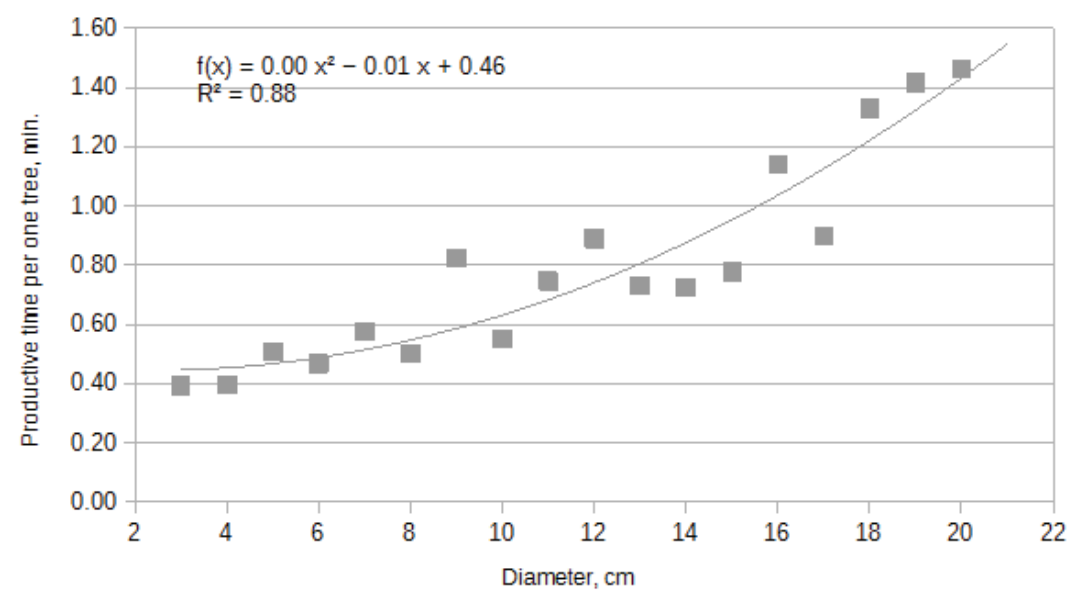

Figure 2. Productive time depends on tree dimensions.

Harvesting productivity in sanitary felling at an average tree of $10 \pm 4 \mathrm{~cm}$ is $5.35 \mathrm{~m}^{3} \mathrm{~h}^{-1}$, number of treated trees per hour is $85 \pm 19$. Similar results have also been achieved in other studies where the productivity achieved in thinning is around $4.5 \mathrm{~m}^{3} \mathrm{~h}^{-1}$ (P.S. Mederski, 2006; P. Mederski et al., 2018). Such results are associated with technical capabilities of single grip harvesters, which determine that time to process a tree does not have a linear correlation with dimensions of tree; therefore, the dimensions of the trees to be processed have a significant impact on productivity (Figure 2).

Opposite impact of dimensions of trees on the productivity rate and number of trees processed per hour is shown in Figure 3. A reduction in the number of trees processed per hour appears when the diameter of extracted trees reaches $12 \mathrm{~cm}$, which is asociated with time consumed for pruning operation, which amounts to $30 \%$ of the total working time.

When analyzing productivity of different forest machine operators, a significant $(<0.05)$ difference is found. The first operator's average productivity is on average $6.2 \mathrm{~m}^{3} \mathrm{~h}^{-1}$ processing 96 trees per hour, the second operator's productivity is $3.95 \mathrm{~m}^{3} \mathrm{~h}^{-1}$, treating 69 trees per hour. The significant differences in productivity are combination to different work planning and experience working with a harvester. The second operator is planning work tree by tree, whereas the first operator plans harvesting order of 5-8 trees.

The test results used in the calculations are indicators of harvesting and delivery, the load size of the logs and the average forwarding distance. The cost calculations use average productivity indicators for

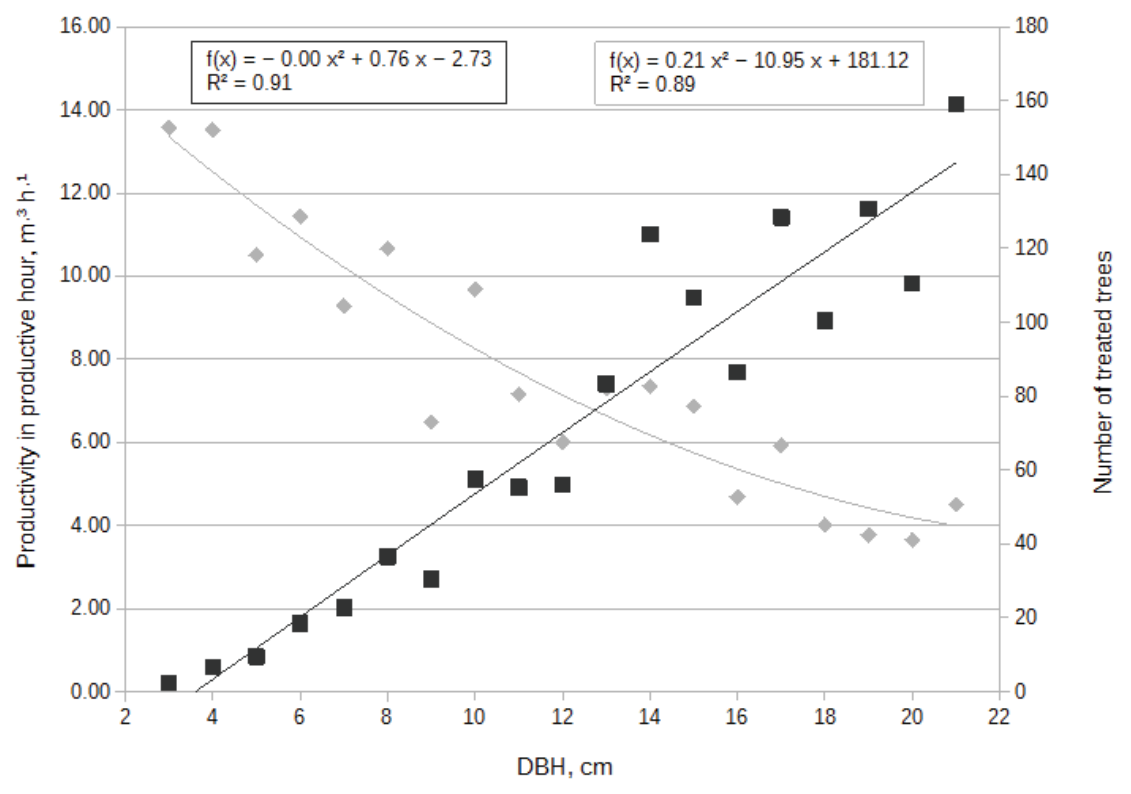

Figure 3. Relationships between productivity and number of cut trees depending on diameter. 


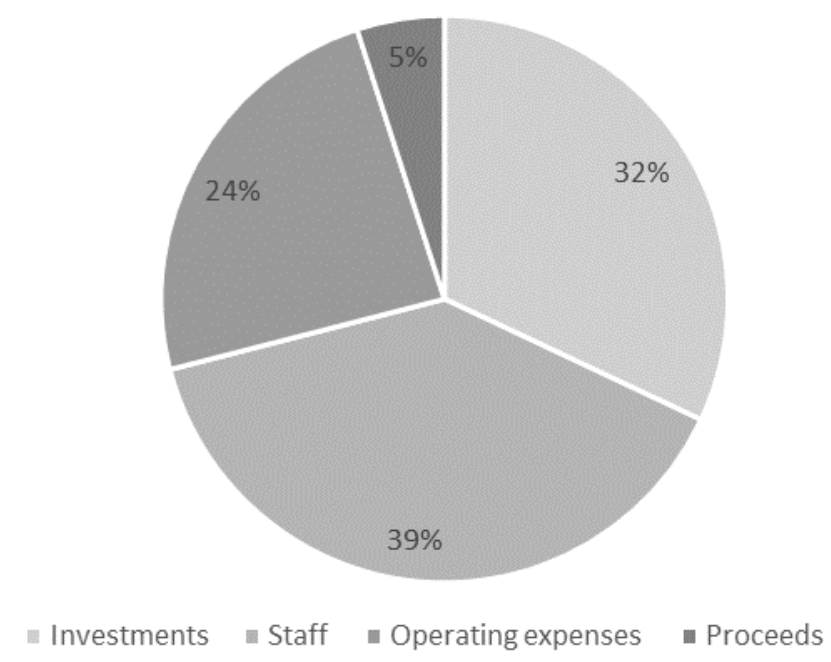

Figure 4. Different positions of harvesting costs.

harvester and forwarder. Direct and indirect harvester costs in all scenarios are the same. The average annual cost of Malwa harvester is $146000 €$. The most of the cost is operational costs, which include variables and part of fixed cost (insurance, taxes). Staff costs are the biggest expense position $(38.9 \%$ of the total cost, Figure 4).

The salary rate of the harvester and forwarder operator use in calculation is 11 €per hour. Similarly, the calculations assume that harvester operators work in one shift for 7 hours. The total number of productive working hours of harvester per year, according to the assumptions, is 1232. Cost of harvester's productive hour is $92 €$. Harvesting costs with Malwa harvester at average productivity and sawn tree dimension rates are $21 € \mathrm{~m}^{-3}$. Fuel consumption in harvesting is 1.2 $\mathrm{L} \mathrm{m}^{-3}$. The average annual cost of Malwa loading is $123000 €$. The calculations assume that forwarder operator performs work in two shifts (duration of a shift 7 hours). The cost of the productive time of the forwarder is $78 €$ per hour. Fuel consumption per $1 \mathrm{~m}^{3}$ is $1.0 \mathrm{~L}$. Cost of round wood production and forwarding with Malwa machines in the trials were $34 € \mathrm{~m}^{-3}$ (Figure 5). In similar studies, forwarder costs are significantly lower (Petaja, Muižnieks, \& Kalēja, 2017; Spinelli \& Magagnotti, 2010). If the total number

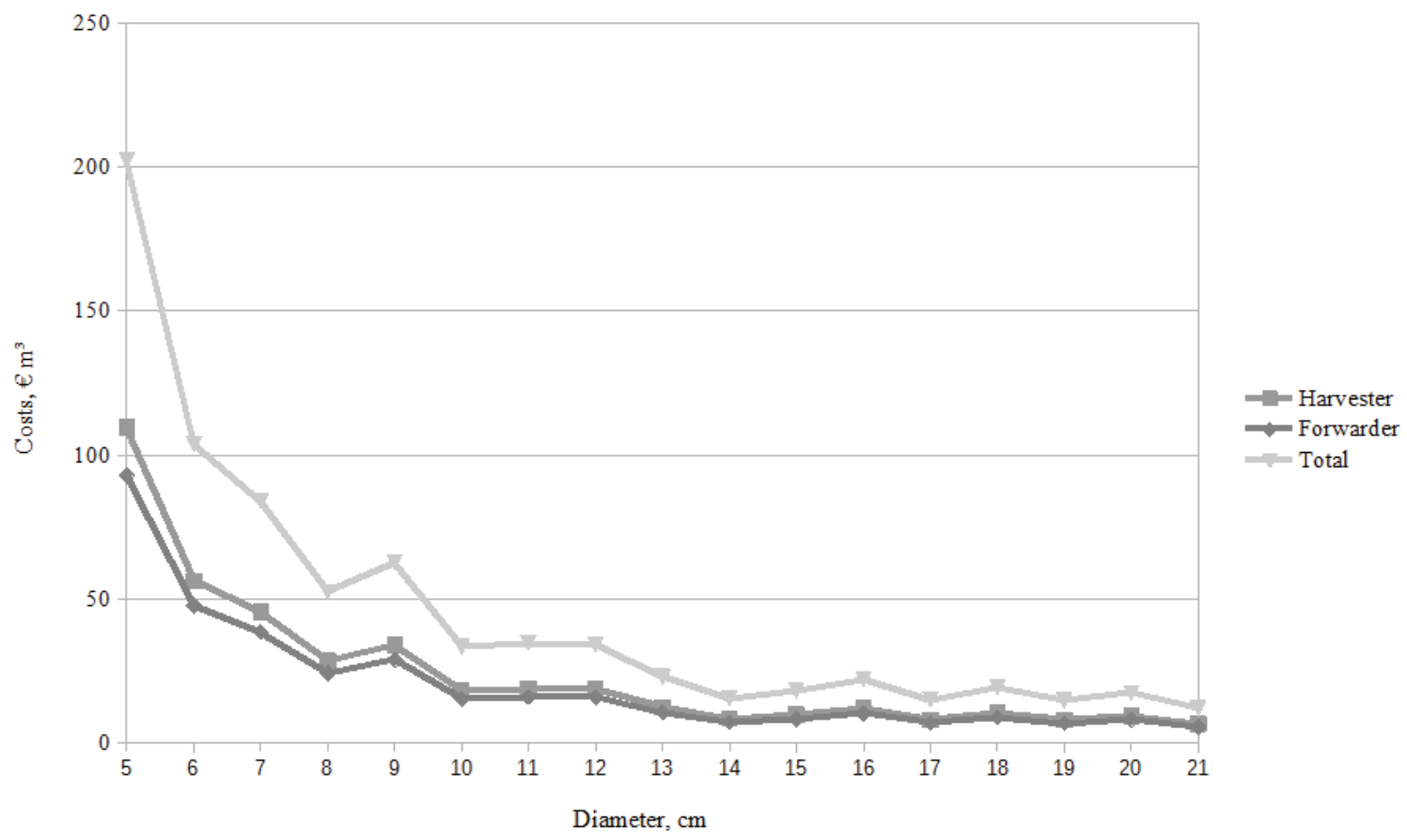

Figure 5. Costs in sanitary felling. 
of shifts from the current one shift to two shifts per day is increased, the production cost would decrease to $21 € \mathrm{~m}^{-3}$. There is insufficient experience in operations of Malwa harvesters; therefore, operational costs may be significantly overestimated by application of a middleclass harvester and forwarder maintenance costs.

\section{Conclusions}

1. In sanitary felling, maintenance in one shift, the cost of timber preparation is $34.10 € \mathrm{~m}^{-3}$, increasing the number of shifts to two, the cost of timber preparation can be reduced by $60 \%$.

2. Average productivity in sanitary cuttings is $5.35 \mathrm{~m}^{3} \mathrm{~h}^{-1}$, at an average tree in DBH $10 \mathrm{~cm}$.
3. The number of trees processed per working hour, which is a notable indicator of the harvester performance in sanitary cutting, ranged on average from 53 to 150 . The highest number of trees processed per hour is a small dimension trees from DBH 3 to $6 \mathrm{~cm}$.

\section{Acknowledgements}

The study was implemented within the scope of the Forest Sector Competence Centre of Latvia No 1.2.1.1/18/A/004 'Approbation of non-standard harvesting solutions in non-conventional felling times'.

\section{References}

CSP (2018). Centrālās statistikas gada grāmata, 2018. (Statistical yearbook of Latvia 2018). Rīga: Centrālā statistikas pārvalde, ISBN 978-9984-06-513-7. (in Latvian).

Donis, J., Saleniece, R., Krisans, O., Dubrovskis, E., Kitenberga, M., \& Jansons, A. (2020). A financial assessment of windstorm risks for Scots pine stands in hemiboreal forests. Forests 2020, 11, 566. DOI: 10.3390/f11050566.

Snepsts, G., Kitenberga, M., Elferts, D., Donis, J., \& Jansons, A. (2020). Stem damage modifies the impact of wind on Norway spruces. Forests 2020, 11(4), 463. DOI: 10.3390/f11040463.

Krisans, O., Saleniece, R., Rust, S., Elferts, D., Kapostins, R., Jansons, A., \& Matisons, R. (2020). Effect of bark-stripping on mechanical stability of Norway spruce. Forests, 11, 357. DOI: 10.3390/f11030357.

Kalēja, S., Lazdiņš, A., Zimelis, A., \& Spalva, G. (2018). Model for cost calculation and sensitivity analysis of forest operations. Agronomy Research, 16(5), 2068-2078. DOI: 10.15159/AR.18.207.

Lazdiņš, A., Prindulis, U., Kalēja, S., Daugaviete, M., \& Zimelis, A. (2016). Productivity of Vimek 404 T5 harvester and Vimek 610 forwarder in early thinning. Agronomy Research, 14(2), 475-484. Retrieved January 21, 2020, from http://agronomy.emu.ee/wp-content/uploads/2016/05/Vol14-_nr2_Lazdins.pdf.

Mederski, P.S. (2006). A comparison of harvesting productivity and costs in thinning operations with and without midfield. Forest Ecology and Management, 224(3), 286-296. DOI: 10.1016/j.foreco.2005.12.042.

Mederski, P., Venanzi, R., Bembenek, M., Karaszewski, Z., Rosińska, M., Pilarek, Z., ... Surus, M. (2018). Designing Thinning Operations in 2nd Age Class Pine Stands-Economic and Environmental Implications. Forests, 9(6), 335. DOI: 10.3390/f9060335.

Petaja, G., Muižnieks, E., \& Kalēja, S. (2017). Efficiency of Vimek 610.2 forwarder and its impact on soil in forest thinning. In Rural Development (p.6). Aleksandras Stulginskis University. DOI: 10.15544/ RD.2017.176.

Rūba, J., Miezīte, O., \& Luguza, S. (2014). Impact of risk factor management on the sanitary condition of Norway spruce (Picea abies [L.] Karst.) pure stands in Latvia. Journal of forest science, 60(5), 181-189. DOI: $10.17221 / 4 / 2014-J F S$.

Šņepsts, G., Bigača, Z., Desaine, I., Jansons, J., Donis, J., Strēlnieks, K., ... Krišāns, O. (2018). Characteristics of damages in Norway spruce stands. In Research for Rural Development (pp. 65-71).

Spinelli, R., \& Magagnotti, N. (2010). Performance and cost of a new mini-forwarder for use in thinning operations. Journal of Forest Research, 15(6), 358-364. DOI: 10.1007/s10310-010-0193-X.

Valsts meža dienests, (2019). 2018. gada Publiskais pārskats. (Public Overview 2018). Rīga. Retrieved January 21, 2020, from https://www.zm.gov.lv/public/files/CMS_Static_Page_Doc/00/00/01/54/24/VMD_ Publiskais_parskats_2018_.pdf. (in Latvian).

Zemkopības ministrija. (2018). Meža nozare skaițlos un faktos (Latvian Forest sector in facts \& figures). Rīga. Retrievesd January 24, 2020, from https://doi.org/https://www.zm.gov.lv/public/ck/files/skaitli\&fakti_ LV_2017.pdf. (in Latvian).

Zimelis, A., Kaleja, S., \& Okmanis, M. (2019). Complex forest management system based on small size forest machines. Engineering for Rural Development, 1, 6. Retrieved February, 14, 2020, DOI: 10.22616/ ERDev2019.18.N021. 